This is an Accepted Manuscript of an article published by Taylor \& Francis in Production Planning \& Control: The Management of Operations on 06/09/2013, available online: http://wwww.tandfonline.com/10.1080/09537287.2013.829252 or http://dx.doi.org/10.1080/09537287.2013.829252.

Citation: Adebanjo, Dotun and Laosirihongthong, Tritos (2014) Adoption of web-based orderprocessing systems: experiences from tier-1 suppliers in the automotive supply chain. Production Planning \& Control: The Management of Operations, 25 (15). pp. 1287-1301. ISSN 0953-7287 (Print), 1366-5871 (Online) (doi:10.1080/09537287.2013.829252)

\title{
Adoption of web-based order processing systems: experiences from tier-1 suppliers in the automotive supply chain
}

This research studies automobile industry suppliers in Thailand, who have implemented VMI using webbased order processing technology. It examines their motivations and barriers for implementing the technology, and identifies the enabling factors with greatest impact on the outcomes of such implementation. Data was obtained from 70 tier-1 suppliers of the two biggest automobile assemblers in Thailand. Exploratory factor analysis was used to construct motivation, enabling factors, difficulties/barriers, and outcomes of web-based order processing technology implementation. Multiple linear regression was then used to examine the relationships between enabling factors and operational outcomes. The results show that improving customer responsiveness and the need to retain competitive advantage rather than cost-based orientation were the primary drivers of implementation of web-based order processing. This case provides insights to enable successful implementation by

organizations that are planning to deploy the technology, particularly in the early stages of technological diffusion in emerging economies.

Keywords: automotive industry; e-purchasing; tier-1 suppliers; VMI; web-based order processing, Thailand

Classification: Research Paper 


\section{Introduction}

The benefits of information and communication technology (ICT) on supply chain operations are identified in many studies (Brunelli and Milligan 2000, Muller and Seuring 2007). Muhge et al. (2004), for instance, suggested that after implementing electronic data interchange (EDI) within an organization and/or web-based order processing between suppliers and buyers in the automotive supply chain, organizations are able to increase data transaction capability, leading to increased visibility of supply chain operations. In addition, those technologies are considered as key organizational resources in supporting firms to create strategic competitive advantage, including cost reduction and improving customer responsiveness (Lo et al. 2008). Auramo et al. (2005) suggested that the key strategic roles of EDI or web-based order processing technology cover the following: (a) Transaction execution: reducing the friction in transactions between members through cost-effective information flow/communication (Telephone, Fax, E-mail, and Internet); (b) Collaboration and Coordination: providing a cost-efficient way to manage suppliers and buyers; and (c) Decision Support: providing assistance for managerial decisions (E-purchasing, ERP software). In the context of the automotive supply chain, suppliers, especially tier-1, have been driven by buyers (automobile assemblers) to adopt those e-purchasing technologies in order to reduce the long-term cost of purchased parts/components, increase the visibility of information flow, increase product customization, and develop build-to-order capabilities (Ageshin 2001).

The need for the study was identified in an earlier study of the ASEAN automotive manufacturing industry by Laosirihongthong et al. (2011). The study found that the vast majority of automobile parts manufacturers were poor at developing information systems that were compatible with their supply chain partners. The study also found that most companies in the sector were poor at 
information sharing and furthermore, there was weak emphasis on inventory-related performance measures. This was the legacy context in the industry prior to the mandated implementation of webbased order processing systems by the OEM automobile manufacturers. It is important, therefore, to understand how the component manufacturers implemented change management to comply with the mandates of the OEM manufacturers.

According to Vigtil (2007), EDI is an enabler of Vendor Managed Inventory (VMI). This paper is focused on the use of VMI-based web ordering systems in Thailand, a developing economy, and based on the activities of the first tier suppliers of original equipment manufacturers (OEMs). The VMI systems used by the OEMs are based on the following process. The system will generate orders either on a monthly or weekly cycle depending on customer orders and inventory status. The generated orders are then translated into web-based purchase orders which the suppliers can access electronically. Based on the purchase orders, the suppliers are then required to print a standardized label including a barcode and attach to the products. The labels improve receipt accuracy and invoice management. The suppliers will then use the web-based system to inform the customers that the products have been shipped prior to physical arrival of the products.

This type of web-based system, while commonly in use in developed economies, is not as common in developing economies such as Thailand. It is important therefore to understand how the supplier community has received and perceives such systems. From a Thai industry perspective, it is also important to understand the difficulties, if any, that implementation of such systems bring as well as understand factors that can enable effective implementation of such technologies. This issues have not been studied in a Thai automotive context and understanding the issues will be of significant benefit to other organizations in the automotive as well as other industries in Thailand that intend to deploy webbased VMI systems. Potentially, it could also hold lessons for organizations in other developing economies. Therefore, this study is based on the phenomenon of adoption of web-based ordering 
systems in supplier companies in developing economies. This study also takes into account the potential impact of employee reaction to a change in working practices through the proxy of labor unions. Previous studies of the ASEAN automotive manufacturing industry Laosirihongthong et al. (2011, 2013) found that people management and the engagement of employees in process management and improvement was poorly developed. The studies also found that leaders did not integrate effectively with their employees. Consequently the implementation of mandated webbased ordering systems could be viewed with suspicion by employees. Anecdotally, employee labor unions in Thailand have been at the forefront of leading resistance to change, and particularly mandated change. The study of the adoption of technological innovation in developing economies is an established strand of research (e.g. Silveira, 2001; Ozcelik and Taymaz, 2004) and this study further contributes to this body of knowledge.

The purpose of this study is to examine the factors that underpin the implementation and success of web-based order processing technology in the automotive supply chain of an emerging economy country. The choice of the context is facilitated by the rapid industralisation of such countries based partly on manufacturing activities of global automotive manufacturers and the expectation that their local suppliers would be expected or required to adopt leading edge technologies. This industry has been considered as a flagship sector frequently regarded as a barometer measuring the current wealth of the economy. The automotive industry is an important sector because automobile production is a large and varied industry (Helper 1991). Achieving efficiency within the supply chain can be a competitive imperative in this industry. The following section reviews the literature. Subsequent sections describe the research methodology, followed by the findings, and conclusions and implications of the study.

\section{Literature review}


In this section, the current status of the Thai automotive industry is described. Next, literature on the implementation of web-based technology in supply chain management, especially in production planning and control, and purchasing function, is reviewed. It is important to note that greater efforts in adopting web-based order processing and enhancing data transaction capability achieved through the use of this technology could enable significant customer responsiveness. E-purchasing, for example, will raise the professional practices of the purchasing function through enhanced internal customer service and significant cost improvement (Hough and Ashley, 1992; Croom 2000, Subramaniam and Shaw 2002).

\subsection{The Thai automotive industry: Practices and policy}

In Thailand, the automotive industry has become one of the most important in the manufacturing sector in the country. This industry has contributed significantly to the rate of employment, GDP, and exports (Thailand Development Research Institute (TDRI) 1999, Bank of Thailand 2000, the Federation of Thai Industries (FTI) 2000). There are three levels of manufacturers in this industry: (a) passenger and commercial vehicle assemblers, (b) component manufacturers, and (c) supporting/equipment manufacturers (Board of Investment 1995, Japan International Cooperation Agency (JICA) 1995). The first level is dominated by sixteen assemblers including the Japanese big five (Toyota, Isuzu, Mitsubishi, Nissan, and Honda), the U.S. big three (Ford, General Motors, and Daimler-Chrysler), and some leading European automakers (BMW and Thai Swedish Assembly). Total production volume of cars in 2007, 2008 , and 2009, was 1.28, 1.39, and 0.99 million units/vehicles respectively (www.thaiauto.or.th).

For the tier suppliers at the second and third level, most companies are owned by foreigners through direct investment, joint venture, and technical licensing arrangements. Presently, there are 1,164 parts and component manufacturers, 850 of which manufacture parts and components in Thailand. Among these manufacturers, 358 are tier-1 suppliers, 272 are tier- 2 suppliers, and 220 are tier-3 suppliers (www.thaiauto.or.th). The development of the automotive industry has also led to 
development in the upstream industries such as petrochemicals and plastics, automotive components, and metal and machinery (Automotive Information Action Group, 1997).

Thailand is developing as a major offshore base for international automotive manufacturers especially Japanese and American. The Japanese Automobile Manufacturers' Association (FTI, 2000) reported that exports from Thailand led the automotive industry revival throughout Asian countries. The automobile industry has been chosen as one of the major strategic industries in Thailand's drive towards modern competitive manufacturing. However, the regional competitive situation in automobile manufacture and export is precarious. In order to respond to increasing demand from global customers and to attract more foreign investment, it is essential that the Thai automotive industry improves cost, quality, and time-based performance in comparison to the automotive industry in other countries in the region. Most companies in the sector have implemented international quality management systems (ISO/TS16949), environmental management standard (ISO 14001), and adopted international operations strategies including just-in-time production system, lean manufacturing, supply chain management, total quality management, and other organizational innovation/intervention (Paul and Laosirihongthong, 1998). In addition, these companies are able to enhance the competitive advantage of their supply chains by investing in e-purchasing through web-based order processing (Gunasekaran et al. 2009).

\subsection{Web-based order systems and VMI}

Web-based order processing is a rapidly evolving area of e-purchasing, which is attractive to many organizations because of the potential payback (IBM Global Procurement, 2000; Lancioni et al, 2000; Panayiotou et al, 2004). The benefits include linkage of ordering and accounts payable, automation of the approval process, improved business intelligence for better decision-making, and reduction of "maverick" (unauthorized) buying. Further advantages of e-purchasing and e-fulfillment through web- 
based order processing technology have been identified in the literature (Hintlian et al, 2001; Wyld, 2002; Muffatto and Payaro,2004) to include better management of the information and knowledge exchange with supply chain partners, better understanding of weaknesses, better control of supplybased operations, more accurate procurement, improved control of sales; warehouse stock optimization, better control of market trends and an increase in the number of products supplied by main suppliers.

VMI is an important aspect of web-based order systems. According to Marques et al. (2010), VMI has shared objectives which enable better collaboration among supply chain partners. These objectives include better supply chain flow and reduction of the bullwhip effect. Caskey et al. (2001) identified specific benefits for both retailers and manufacturers. For retailers, the benefits are reduction in management time, administration costs and warehouse space required while for manufacturers, benefits include improved stability in demand, manufacturing planning and a reduction in inventory and administration costs. Other benefits of VMI that have been identified in literature include minimization of information distortion, better capacity utilization, reduced transportation cost, better dynamic response, increased customer satisfaction (Song and Dinwoodie 2008), better transparency and demand visibility in the supply chain (Vigtil 2007).

The potential benefits to be gained from VMI have encouraged some researchers to examine the enablers of VMI success in an effort to maximize the gains from VMI implementation. According to Claassen et al. (2008), enablers for successful VMI implementation include honesty, openness, trust, mutual interdependency, interaction frequency, commitment, information sharing (completeness, accuracy, ease of access, timely) and quality of information systems. In addition, Marques et al. (2010) identified trust and medium/long term collaboration as important success factors. However, irrespective of the benefits to be gained from VMI, several studies have identified problems with its implementation. Studies by Marques et al. (2010) and Kauremaa et al. (2009) raise questions about the 
benefits to suppliers with the former suggesting that there is potential for inventory to build up with suppliers. Interestingly, Sari (2007) suggested that lot of problems related to VMI are due to supplier performance. Kaipia et al. (2002) suggested that VMI was not standardized in industry as a result of these types of problems.

The motivation for this study is based on understanding the enabling factors, outcomes and barriers from the perspective of the automobile industry in Thailand. Although Thailand is an important manufacturing base, no previous study on VMI-based web ordering systems has been carried out in the country. The need for the study is further motivated by the fact that adoption characteristics and success factors of VMI-based web ordering systems can vary by geography and industry. According to a study by Seyal et al. (2007), government support is a key factor for adoption of EDI in Brunei while Dorling et al. (2006) suggested that the factors for successful implementation of VMI in the food industry were specific to that industry. Consequently, it is important from the point of view of Thai industry, and the automobile industry in particular, that the factors and obstacles that relate to web order systems adoption in the country should be researched.

\subsection{Diffusion of web-based order processing technology in the automobile industry}

According to Childerhouse et al. (2003a), the schedules of OEMs in the automobile industry are extremely volatile and are liable to cause disruption further upstream in the supply chain. This will negatively affect the efficiency of supply chain operations. In an effort to improve the efficiency of interorganizational supply chain operations, much emphasis has been placed on the implementation of ebusiness tools and techniques. In a discussion of EDI deployment in the supply chain, Leonard and Davis (2006) suggested that EDI enables better information flow. In particular EDI can reduce errors and 
improve the accuracy of information exchanged. EDI also allows order entry to become faster and cheaper while eliminating the need for manual re-entry of data. Thus, this technology helps to reduce inventory in the supply chain while improving customer satisfaction as well as the level of customer responsiveness. It is also important to note that many of the costs associated with poor scheduling and inventory management can be eliminated by improving the flow of order and demand information upstream in the supply chain (Mullins et al, 2002; Childerhouse et al. 2003b).

However, the deployment of such technologies is not without its challenges. In a study of EDI implementation especially in the automotive industry, Lauer (2000) found that mandated implementation of EDI order processing by OEMs can lead to ripple effects and cause problems for suppliers that are not ready for the adoption of such technologies or whose legacy systems or processes are not compatible with the new technology. Childerhouse et al. (2003b) further noted that there are several barriers to the implementation of information flow technologies in the supply chain and classified these barriers into four categories - technological competencies, cultural difference, financial constraints, and organizational behavior. The issue of technological competencies primarily relate to multiple standards and inflexibility of EDI systems. Cultural differences are manifested in unwillingness to share information and the potential of dominance and power imbalance in the supply chain. Financial constraints are evident in the determination of which supply chain partners will bear the cost of implementation of the technology. Organizational constraints relate to the integration of supply chains across organizations and the difficulties inherent in attempting integration.

In conclusion, after reviewing literature, this study found that web-based order processing technology is able to enhance inter-organizational coordination, resulting in transaction cost savings and competitive sourcing opportunities for both supplier and the buyer organization. However, there are also potential barriers and challenges to implementation. For organizations in the Thai automotive industry, the costs and effort required to implement web-based VMI systems are significant and the 
organizations need to be certain that this technology is implemented efficiently and effectively. Hence, two research questions were posed and explored:

Research Question 1: What are the motivations, benefits/outcomes, and difficulties/barriers in implementing web-based order processing among tier-1 suppliers in automotive supply chain in Thailand?

Research Question 2: What enabling factors most affect the operational outcomes of web-based order processing technology implementation in Thailand?

In the next section, the research methodology including survey instrument development, data collection, non-respondent bias, and reliability and exploratory factor analysis are described.

\section{Research Methodology}

A two-stage methodological approach was adopted for the study. The first stage which was quantitative in nature required the use of a questionnaire study among tier- 1 automotive suppliers in Thailand. The second stage which was qualitative in nature required the use of semi-structured interviews at automotive assemblers, a tier-1 supplier and a VMI system developer. The interviews were used to validate the findings from the questionnaire study.

\subsection{Survey instrument development}

This study used pre-tested scales from past empirical studies to ensure their validity and reliability, based on the suggestion made by Tata et al. (1999). The scales for competitive/business focus, enabling factors, expected operational outcomes, and obstacles/difficulties in implementing web-based order 
processing used in this study were adapted from previous studies by Childerhouse et al. (2003a), Lyons et al. (2004), Soares-Aguiar and Palma-dos-Reis (2008), Lauer (2000), Leonard and Davis (2006), and Childerhouse et al. (2003b) respectively. The content and rationale of the scales is briefly described below.

For competitive/business focus, a scale representing a set of both proactive and reactive strategy was determined. This includes being the fast follower within the industry, dealing with technological change, increasing sustainable competitiveness, reducing inventory levels within the supply chain, increasing communication and capability in data processing within the company, and increasing information transactions capability between the company and its customers. It is important to note that these scales cover the basic concepts of the development of competitive advantage (Porter 1998).

In order to achieve the expected benefits in implementing web-based order processing technology, the scales representing enabling factors were derived from the study of Lyons et al. (2004), and Soares-Aguiar and Palma-dos-Reis (2008). The content captures technology competence, leadership, and systems integration. These scales not only reflect the technical aspect of adopted technology, but also the firm's commitment to adapt an organizational culture, which is strongly connected with system integration within and between organizations.

Expected operational outcomes in implementing web-based order processing technology include increasing the degree of customer satisfaction, increasing the ability to share information between the company and its customers, reducing the loss of purchasing documents, increasing accuracy in purchasing and production planning, increasing customer (assemblers) responsiveness, reducing the cost of manufacturing, and reducing the inventory level of raw materials and work-inprocess (WIP). Therefore, the scale represents the focus on customer responsiveness (Lauer 2000, Leonard and Davis 2006). 
Finally, to identify the potential obstacles/difficulties in implementing this technology, resourcebased view (RBV) theory was used to identify the scales (Karia and Wong, 2012). The concept of this theory addresses considerations such as how much organizational resource does a company have, how they are integrated with the competitive advantage of the firm and how they are released. Hence, these scales include lack of a capable network/system service provider, inaccuracy of existing data in the company, lack of co-ordination and communication between the company and its service provider, high frequency of software technological change, incompatibility between existing data and applicable software/operating systems, lack of customer (assemblers) support, high initial investment cost, inadequate knowledge and skills of users, and lack of top management support.

All items in the four constructs used a six-point Likert scale. The scales of competitive/business focus ranged from strongly disagree (1) to strongly agree (6). The scales for enabling factors ranged from (1) not at all to (6) a great extent. Obstacles/difficulties ranged from less important (1) to very important (6). For expected outcomes from implementing web-based order processing technology, the

scale ranged from (1) worst in industry to (6) best in industry as compared with competitors. A complete list of the items used in this study is presented in the Appendix.

The questionnaire was pre-tested through interviews with procurement/purchasing managers, production planning and control department managers, academics, and ERP system vendors who assessed its overall quality and level of understanding. Based on the results of the pretesting, the questionnaire was slightly modified in order to improve data validity and reliability.

\subsection{Data collection and profile of respondents}

In this study, the questionnaires were sent to 230 tier-1 suppliers of two automobile assemblers (Japanese and American) located in Thailand. These two assemblers are the top two companies in terms of annual production volume and their suppliers represent $90 \%$ of the total tier- 1 automotive suppliers 
in Thailand excluding motorcycle manufacturers. These suppliers include the manufacturers of key parts/components including engine, frame and body, suspensions components, and electrical components. In addition, these suppliers were required, since 2006, by the automobile assemblers to adopt web-based order processing application in order to support the VMI system at those two assemblers. Their experiences in implementing this technology ensure a relatively high level of maturity of obtained data. Middle to top management staff working in the production planning and control function were the target respondents. A total of 74 completed responses were received, implying a 32.17 per cent response rate. Compared with previous studies, this returned rate is acceptable and reflective of the population (Gunasekaran et al. 2009, Zhang and Dhaliwal 2009). There were 4 questionnaires that were discarded due to excessive missing responses, thus resulting in 70 usable responses. Table 1 presents the key characteristics of respondents involved in this study.

(Insert Table 1 about here)

The result shows that the majority of respondents are electrical components, engine power transmission components, frame and body manufacturing firms respectively. Approximately sixty five per cent of the respondents are large companies with 200 employees or more. The working experience of respondents is at least 2 years in production planning and control function, which helps to ensure the accuracy of the information they provided for this study. With respect to the type of ownership of firm, 80 per cent (approximately) of respondents are foreign-owned through joint venture (53 per cent) and direct investment (28 per cent). Only 20 per cent are Thai-owned. Forty per cent of respondents have labour unions. Finally, all firms have adopted at least one international standard of management systems/standards including ISO9001:2000, ISO 14001:1996, and ISO/TS-16949: 2002.

In order to investigate non-response bias in the survey data (Lambert and Harrington 1990), the 
collected data was tested for statistical differences in responses and firm characteristics between the early and late waves of returned surveys. The last wave of returned survey was found to be representative of the whole sample. Independent samples t-tests did not yield any statistically significant difference between the two groups, suggesting that non-response bias was not an issue in this study.

\subsection{Reliability and exploratory factor analysis}

Validity and reliability examination were carried out for the all constructs (Tables 2-5). Reliability analysis was conducted by examining the value of Cronbach's $\alpha$ (Cronbach 1951) for each extracted construct. Results showed that in each case, values of $\alpha$ exceeded the suggested threshold value of 0.6 (Nunnally 1978). Since Cronbach's a may under-estimate error caused by external factors such as differences in testing situations and respondents over time, composite reliability and average variance extracted were also examined since they are more parsimonious measures of reliability (Podsakoff et al. 2003). Statistics for composite reliabilities for each of the extracted constructs exceeded the required threshold value of 0.70 , providing further evidence of scale reliability (Chin 1998).

In order to answer research question 1, exploratory factor analysis with principal components analysis was then employed to investigate the uni-dimensionality of the scales/variables. Factor loadings of all items within each scale were above 0.50 , providing support for the validity of measuring the latent variables using the respective sets of indicators. Values of the Kaiser-Meyer-Olkin (KMO) measures of sampling adequacy in excess of 0.50 (Kaiser 1974, Falk and Miller 1992) indicated that the use of factor analysis was appropriate, and that extracted factors were distinct and reliable. This is reaffirmed by the fact that for each scale, Bartlett's sphericity test for the null hypothesis that the correlation matrix is an identity matrix, was rejected $(\alpha=5 \%)$. Tables $2-5$ present the results of exploratory factor analysis with the Varimax rotated component matrix. In order to ensure that there is 
no effect of organizational characteristics on all extracted factors, ANOVA with a post hoc test was conducted and the result indicated an insignificant effect of size of company (measured by number of employees), type of ownership, labor union, and obtained international standards for management systems on all extracted factors.

\subsection{Semi-structured interviews}

Based on findings from the questionnaire surveys, semi-structured interviews were held at three organizations, namely an automotive assembler, a tier-1 supplier and a web ordering system developer. The interviews were held with various personnel within the organizations including VMI project managers, programmers, production planning and control managers and supervisors. The interviews were used to validate findings from the questionnaire study and focused on gaining in-depth insight of the motivation, enabling factors and barriers encountered in the adoption of VMI via web-based systems. The semi-structured interviews were underpinned as well by the research questions and were based on the concept that automotive assemblers in developing countries like Thailand require motivation to adopt emerging technologies. In addition, the enabling factors that affect them may differ

from those in developed economies and details are better identified through semi-structured interviews.

\section{Findings from the Study}

4.1. Motivation, enabling factors, and difficulties/barriers in implementing web-based processing 


\section{technology}

With respect to the motivation for implementing web-based order processing technology, Table 2 shows the results from two perspectives - operational improvement focus and long-term strategy focus. The composite mean shows that companies consider the level of importance in adopting webbased order processing technology to be high. With respect to the operational improvement focus, the findings indicate that the respondents place greatest emphasis on increasing information transaction capability with their customers followed by increased ability to process operational data, increasing internal communication capability, and reduction of inventory levels in the supply chain. The VMI project manager of the automotive (One ton pick-up) assembly company validated these findings by saying:

“Our company has decided to apply web-based order processing systems to all tier 1 suppliers since 2009. As a result, all data and information are more visible and the system provides an accurate delivery schedule for the production planning and control department of our company and suppliers".

The department manager of the production planning and control department of a tier-1 supplier said:

"Before adopting VMI, our sales engineer/production planning and control officer had to pick-up purchase order document when he/she attended the supplier monthly meeting at the customer's plant. Due to other meetings within a week, it took a couple days for them to bring this information back to us and put into our production planning system. This led to a gap between our company and the customer when they start counting the date and time to place oreders. Fortunately, after implementing VMI systems, our company gained lots of benefits including reducing inventory level, reducing purchasing lead-time, reducing number of sale persons, and increasing accuracy of data and information from the customer and information sharing with our internal departments". 
With respect to long-term strategy focus, the greatest emphasis was placed on responding quickly to changes in the industry, increasing competitive advantage, and response to the speed of change of webbased technology respectively.

(Insert Table 2 about here)

Table 3 presents the findings relating to the enabling factors in three different constructs - technology readiness, leadership, and systems integration. The composite means of those three constructs show that technology readiness is the most important enabler in implementing web-based order processing technology followed by leadership, and systems integration. This finding confirms the study of Zhu et al. (2003) and Hong and Zhu (2006), which indicated that the web functionalities, technology competence, and technology integration were significant facilitators in internet-based e-commerce implementation in European countries, and US and Canada.

For the technology readiness construct, continuous training and education was seen as requiring most emphasis. Some evidence for this was provided by the VMI system vendor who said:

"Most of our clients who have implemented VMI software (web-based) solution considered internal productivity improvement (i.e. time-based flexibility, accuracy, and responsiveness) as the main purpose. However, they still lack technological compatibility which includes identification of adequate user requirements, compatibility between existing (legacy) systems and new ITarchitecture, stability of computer and communication networks, and user-friendly interface". 
With respect to leadership, top management commitment and financial support was seen to be most important. This finding is in line with evidence provided by a programmer at the automotive (One ton pick-up) assembler who said:

"During the designing and rolling-out stage of the VMI project, more frequent communication among system vendor, programmer, and users is the most important factor for success. Weekly and monthly meetings were used by the project team in order to make sure that all necessary user requirements (i.e. data transactions, compatibility with an existing IT platform, and web-page design) were identified and communicated to the system developer. Finally, periodic training (pre and post implementation) had to be organized for all users who were responsible for using this system in assemblers and tier- 1 supplier companies".

(Insert Table 3 about here)

Table 4 shows the results with respect to the expected outcomes of web-based order processing with customer responsiveness being the singular classification. Increasing the degree of customer satisfaction was the most important outcome.

(Insert Table 4 about here)

Table 5 shows the barriers/difficulties faced by respondents under two constructs - deployment capability, and technology-related resources. The composite mean indicates that the most important barrier/difficulty in implementing web-based order processing technology is technology-related resource (4.087). This finding confirms the study of Melville et al. (2004) which found that the two types of organizational resources that companies have encountered with are technological IT resources (i.e. investment in organizational infrastructure) and human IT resources (i.e. skilled staff and management 
commitment). In addition, the findings of this study also partly confirm the study of Gunasekaran et al. (2009). Their study revealed that that top five barriers inhibiting the migration of e-purchasing technology were poor top management initiatives, fear of change to a new system, immaturity of the technology, lack of skills and knowledge in e-purchasing, and insufficient financial support.

With respect to deployment capability, the high frequency of technological change was seen as the most important obstacle to implementing web-based order processing. This finding is in line with evidence provided by the project manager of VMI systems of the automotive (One ton pick-up) assemblers who said:

"At the intitial stage, we encountered the problem of imcompatibility between exisitng data format and applicable software solutions. IT architecture and type of data had to be re-configured since MRP II system (AS 400 and SAP) has been used by our company and key suppliers. It took us a couple of months to solve these difficulties using support from our system vendor".

For technology-related resources, the high initial investment cost was seen as the most important obstacle, followed by inadequate knowledge and skills of users, and finally, lack of top management support.

(Insert Table 5 about here)

\subsection{Linear Regression Models}

To answer research question 2, multiple linear regression was carried out to examine relationships between the three extracted enabling factors and customer responsiveness for each cluster based on the size of the company and the existence of a labour union. The size of company was chosen because of the resource implication of implementing VMI and labour union was chosen because of the perceived impact of technological change on operational routines in production planning and control (Marques et al, 2010). The multiple regression model for cluster of small to medium size company was statistically 
significant and this model fit is satisfactory (Nurmilaakso 2008). However, only systems integration $(\beta=$ .650) yielded a significant relationship with customer responsiveness. The model for cluster of large size company was again significant.

(Insert Table 6 about here)

Interestingly, this model exhibited significant relationships between customer responsiveness and both technology readiness and leadership. However, there was no significant relationship between this performance and systems integration. The differences between the large organizations and the SMEs may be due to their operational-focus. Smaller companies are likely to have less IT expertise and resources (Eshelman et al. 2001) and as such, the ability to integrate their systems with those of the manufacturer (assemblers) is likely to be seen as crucial. Large organizations, on the other hand, are more likely to have IT resources that would have enabled them integrate their systems with customers (assemblers). There is evidence to suggest that SMEs continue to lag behind larger organizations with respect to the adoption of IT solutions (Duan et al. 2002; O'Toole 2003,). This finding confirms the study of Nurmilaakso (2008) showing that large companies often have the resources to move ahead in adopting new e-business systems. Therefore, systems integration may be accepted as a given in large organizations and their customer responsiveness may be viewed to be more dependent on other enablers such as technology readiness and leadership.

(Insert Table 7 about here)

Table 7 presents the results of multiple linear regression that examines relationships between enabling factors and customer responsiveness based on existing labour union. The hierarchical multiple 
regression model for cluster of company with labour union was statistically significant and the model fit is satisfactory (Nurmilaakso 2008). Both leadership $(\beta=.1081)$ and systems integration $(\beta=.581)$ yielded a significant relationship with customer responsiveness. The model for cluster without labor union was also significant. This model showed significant relationships between customer responsiveness and both technology readiness and systems integration. There was no significant relationship between this performance and leadership.

Interestingly, both clusters indicate that systems integration plays an important role in implementing technology, irrespective of the existence of a labor union. However, for the cluster with labor unions, leadership was also seen as significant. This may be because the activities of the labor union could affect organizational operations and consequently impact customer responsiveness. Consequently, leadership would be important in addressing potential inefficiencies. For the cluster without labor unions, the emphasis on leadership was much less important and more focus was placed on technology readiness.

\section{Discussion}

The results suggest that the need to improve process efficiency and to satisfy customers were the more important drivers of adoption. This finding is partly supported by the fact that the most important issue with respect to motivation for implementing the technology was increasing information transaction capability with customers. The next most important motivational factors were being able to respond quickly to changes in the industry and improving operational data processing. Therefore, in addition to improving interaction with customers, the need to remain competitive was considered to be very important. Interestingly, the least important motivational issue was the reduction of inventory in the supply chain therefore, suggesting that cost-related measures are not the most important issues for the respondents. With respect to the barriers to implementing the technology, cost of implementation, clock-speed of technology change (technology life-cycle), and inadequate technical skills were the most 
important barriers/difficulties while top management commitment and customer support were among the least. The implication is that there is a willingness in the Thai automotive supply chain to implement the technologies.

When viewed from the perspective of a developing economy country, this indicates that the first tier suppliers are very responsive to the demands of their customers who mandated them to adopt web-based order processing technology. The fact that top management commitment was not only identified as the most important enabling factor but was also identified as the least problematic barrier may indicate that such adoption was viewed by senior management as an important strategic decision with potential for positive outcomes for the suppliers.

While there have been studies that suggest that adoption of such technologies are sometimes the result of pressure by supply chain partners and that in such mandated cases, they can lead to problems (Lauer, 2000; Childerhouse et al. 2003b; Chwelos et al. 2001), this study indicates that this is not the case with Thai automotive manufacturers. Many problems with technology adoption are probably caused by an unwillingness or lack of readiness to implement such technologies and simply reacting to the demands of supply chain partners. However, with respect to Thai manufacturers, not only is there senior management support to satisfy customers by adopting the mandated technology, the results also indicate a clear understanding and acceptance that implementing such technologies is an important element of a long-term strategic focus. It is perhaps for this reason that, cost reduction was indicated to be the least important outcome of technology implementation by the respondents while operational improvement outcomes were highly rated.

The findings from the structured interviews also clearly support the focus on operational improvements. One of the suppliers found that implementing web-based order processing led to inventory, lead-time, human resource and data efficiencies and improvements. Furthermore, the system vendor indicated that most clients were motivated by internal productivity improvements such 
as flexibility and responsiveness. The implication for production planning and procurement can be significant. Not only can improved data accuracy facilitate better production planning but the indicated flexibility, responsiveness and reduced lead-times can shorten the production cycle and lead to improved manufacturing efficiencies.

In addition, while the high initial investment cost of such technology continues to be a concern, Thai automotive manufacturers, in general, rated the barriers and difficulties faced to be much lower than other constructs that were measured in this study. The suggestion is that the infrastructure and the culture in the industry are supportive of such technological adoption. This was further evidenced by findings from the structured interviews which indicated a great degree of communication and teamwork between the supply chain partners and the system developers while the issues of IT architecture incompatibility were firmly and promptly addressed.

\section{Conclusions and Implications}

This study has presented the experiences of tier-1 suppliers of the automobile industry who have implemented web-based order processing technology in an emerging economy country. Overall, the study has shown that the obstacles and difficulties faced by the respondents were, in general, ranked lower than the other constructs - expected outcomes, enabling factors, and motivation. With respect to the enabling factors for adopting this technology, the three important extracted factors were top management commitment and financial support, continuous education and training, and knowledge and expertise of the users. This suggests that some of the skills and support issues are as important as the technological issues. With respect to the expected outcomes of implementing this technology, increasing the degree of customer satisfaction, reducing loss of documents and increasing the accuracy of production planning were the most important issues under the extracted factor of customer responsiveness. These issues which relate to process efficiency and customer focus were seen to be 
more important than the cost-based measures - reducing the cost of manufacturing and reducing inventory levels. This is an important finding as it shows that direct cost is not necessarily the primary reason for implementing these technologies and may reflect the role that the customers have played in requiring the implementation of the technologies.

This study has important implications for practitioners and academics. For practitioners, there is the need to clearly understand the reasons for implementing web-based order processing technology. In this regard, the satisfaction of customers and the improved efficiency of internal operations should be paramount. It is also important to note that the roles of management support and the development of appropriate technical skills are crucial to successful deployment of technology. A well designed action agenda in implementing this technology among suppliers, customers (assemblers), and IT system vendors leads to enhancement in absorptive capability of users. While the cultural acceptance of new technology can be problematic, particularly in developing economies, Thai automotive manufacturers have positively embraced web-based order processing technology and integrated it into their long-term strategy. This is an important lesson for manufacturers in other developing economies. For academia, this study indicates the need for continuing research into how technology can be deployed and enables the efficiency of supply chains operations by considering the resource-based view theory. While many of the benefits of technology deployment are recognized, the factors and processes that underpin successful implementation of new technology along the supply chain should be the focus of future research.

Finally, it is important to identify the study's limitations. The study is based on the experiences of only one industry which is seen as a leading industry in the study country. Thus while the results may be of benefit to other industries, it may not reflect their practices or performance.

\section{Acknowledgement}


The authors would like to thank the two automobile assemblers in Thailand, and respondents working in all case study companies for giving such valuable information about the history and practical points of view of their adoption and adaptation of web-based order processing technology. We also would like to thank the Higher Education Research Promotion and the National Research University Project of Thailand's Office of the Higher Education Commission for financial support. The authors would also like to thank Thammasat University and the Faculty of Engineering, Thammasat University for their support.

\section{References}

Ageshin, E., 2001. E-procurement at work: A case study. Production and Inventory Management, First Quarter, 48-53.

Auramo, J., Kauremaa, J., and Tanskanen, K., 2005. Benefits of IT in supply chain management: an exploratory study of progressive companies. International Journal of Physical Distribution and Logistics Management, 35 (2), 82-100.

Automotive Information Action Group (AIAG), 1997. Manufacturing Assembly Pilot (MAP) Project. Final Report AIAG Southfield MI.

Bank of Thailand, 2000. The Economics Report during January - March 2001, 65-80 (in Thai).

Board of Investment, 1995. Report on the Investment in Automotive Industry in Thailand. Bangkok (in Thai).

Brunelli, M.A. and Miligan, B., 2000. Ford and GM drive to build E-procurement systems. Purchasing, $128(2), 139-140$.

Caskey, K., Hunt, I., and Browne, J., 2001. Enabling SMEs to take full advantage of e-business. Production Planning and Control, 12 (5), 548-557.

Childerhouse, P., Hermiz, R., Mason-Jones, R., Popp, A., and Towill, D.R., 2003a. Information flow in automotive supply chains - present industrial practice. Industrial Management \& Data System, 
$103(3), 137-149$.

Childerhouse, P., Hermiz, R., Mason-Jones, R., Popp, A., and Towill, D.R., 2003b. Information flow in automotive supply chains - identifying and learning to overcome barriers to change. Industrial Management \& Data Systems. 103 (7), 491-502.

Chin, W.W., 1998. Issues and opinion on structure equation modeling. Management Information Systems Quarterly, 22 (1), 7-16.

Chwelos, P., Benbasat, I. and Dexter, A.S. (2001), "Empirical test on EDI adoption model”, Information Systems Research, 12(1), 304-21.

Claassen, M., van Weele, R., and van Raaij, E., 2008. Performance outcomes and success factors of vendor managed inventory. Supply Chain Management: An International Journal, 13 (6), 406414.

Croom, S.R., 2000. The impact of web-based procurement on the management of operating resources supply. Journal of Supply Chain Management, 36 (1), 4-13.

Dorling, K., Scott, J., and Deakins, E., 2006. Determinants of successful vendor managed inventory relationships in oligopoly industries. International Journal of Physical Distribution and Logistics Management, 36 (3), 176-191.

Duan, Y., Mullins, A., Hamblin, D., Stanek, S., Sroka, H., Machado, V. and Araujo, J. (2002). Addressing ICTs skill challenges in SMEs: insights from three country investigations", Journal of European Industrial Training, 26(9), 430-441

Eshelman, R., Juras, P., and Taylor, T., 2001. When small companies implement big systems. Strategic Finance, $82(8), 28-33$.

Falk, R.F. and Miller, N.B., 1992. A Primer for Soft Modeling. University of Akron Press. Akron.

Federation of Thai Industries: FTI, 2000. Report on the Thai Automotive Industry. Working group on 
automotive industry. Bangkok (in Thai).

Gebauer, J., Beam, C., and Segev, A., 1998. Impact of the Internet on procurement. Acquisition Review Quarterly, 14, 167-181.

Gunasekaran, A., McGaughey, R.E., Ngai, E.W.T., and Rai, B.K., 2009. E-Procurement adoption in the South coast SMEs. International Journal of Production Economics, 122, 161-175.

Helper, S., 1991. How much has really changed between US automakers and their suppliers. Sloan Management Review, Summer, 15-28.

Hong, W. and Zhu, K., 2006. Migrating to Internet-based e-commerce: Factors affecting e-commerce adoption and migration at the firm level. Information Processing and Management, 43 (2), 204221.

Hintlian, J.T., Mann, R.E., and Churchman, P., 2001. E-Fulfillment Challenge-the Holy Grail of B2C and B2B E-Commerce Accenture White paper.

Hough, H.E. and Ashley, J.M., 1992. Handbook of Buying and Purchasing Management, Prentice-Hall, Englewood Cliffs NJ.

IBM Global Procurement, 2000. A Corporate View on E-Procurement Projecting IBM Through the Supply Chain. State of lowa ERP Migration Plan.

Japan International Corporation Agency, 1995. The study on industrial sector development supporting industries in the kingdom of Thailand. Tokyo: Unico International Corporation (in Thai).

Kaipia, R., Holmstrom, J., and Tanskanen, K., 2002. VMI: What are you losing if you let your customers place orders? Production Planning and Control, 13 (1), 17-25.

Kaiser, H.F., 1974. An index of factorial simplicity. Psychometrika, 39, 31-36.

Kauremaa, J., Smaros, J., and Holmstrom, J., 2009. Patterns of vendor managed-inventory: findings from a multiple-case study. International Journal of Operations and Production Management, 29 (11), 
1109-1139.

Karia N. and Wong C.Y., 2012. The impact of logistics resources on the performance of Malaysian logistics service providers. Production Planning and Control, iFirst, 1-18

Lambert, D.M. and Harrington, T.C., 1990. Measuring non-response bias in mail surveys. Journal of Business Logistics, 11 (2), 5-25.

Lancioni, R.A., Smith, M.F., and Oliva, T.A., 2000. The role of the Internet in supply chain management. Industrial Marketing Management, 29, 45-56.

Laosirihongthong, T., Tan, K-C. and Adebanjo, D. 2011. Supply Chain Management in ASEAN Automotive Manufacturing Industry. International Journal of Logistics: Research and Applications, 14(5), 317-333.

Laosirihingthong, T., Teh, P-L and Adebanjo, D. 2013. Revisiting Quality Management and Performance. Industrial Management and Data Systems, 113(7)

Lauer, T.W., 2000. Side effects of mandatory EDI order processing in the automotive supply chain. Business Process Management Journal, 6 (5), 366-375.

Leonard, L.N.K. and Davis, C.C., 2006. Supply chain replenishment: before-and-after EDI implementation. Supply Chain Management: An International Journal, 11 (3), 225-232.

Lo, W.S., Hong, T.P., and Jeng, R., 2008. A framework of E-SCM multi-agent systems in the fashion industry. International Journal of Production Economics, 114, 594-614.

Lyons, A., Coronado, A., Kehoe, D., and Coleman, J., 2004. Improving the synchronization of supply chains: an automotive case study. International Journal of Automotive Technology and Management, 4 (4), 374-383.

Marques, G., Thierry, C., Lamothe, J., and Gourc, D., 2010. A review of Vendor managed Inventory (VMI): From concept to processes. Production Planning and Control, 21 (6), 547-561. 
Melville, N., Kraemer, K., and Gurbaxani, V., 2004. Information technology and organizational performance: An integrative model of IT business value. Management Information Systems Quarterly, 28 (2), 283-322.

Muffatto, M. and Payaro, A., 2004. Implementation of e-procurement and e-fulfillment processes: A comparison of cases in the motorcycle industry. International Journal of Production Economics, 89 (3), 339-351.

Muhge, G., Hertwig, M., and Tackenberg, H., 2004. More competition more cooperation: E-business and transaction of the automobile supply industry. International Journal of Automotive Technology and Management, 4 (4), 308-323.

Muller, M. and Seuring, S., 2007. Reducing information technology - based transaction costs in supply chains. Industrial Management \& Data Systems, 107 (4), 484-500.

Mullins, D.Y., Hamblin, A., Stanek, D., Sroka, S., Machado, H., and Araujo, J., 2002. Addressing ICTs skill challenges in SMEs: insights from three country investigations. Journal of European Industrial Training, 26 (9), 430-441.

Nunnally, J., 1978. Psychometric Theory, McGraw-Hill, New York, NY

Nurmilaakso, J.M., 2008. Adoption of e-commerce functions and migration from EDI-based to XMLbased e-business framework in supply chain integration. International Journal of Production Economics, 113, 721-733.

O'Toole, T., 2003. E-relationships - emergence and the small firm. Marketing Intelligence and Plan, 12 (2), 115-122.

Oszelick, E., Taymaz, E., 2004. Does innovativeness matter for international competitiveness in developing countries? The case of Turkish manufacturing industries. Research Policy 33, 409-424

Panayiotou, N.A., Gayialis, S.P., and Tatsiopoulos, L.P., 2004. An e-procurement system for 
governmental purchasing. International Journal of Production Economics, 90, 79-102.

Paul, H. and Laosirihongthong, T., 1998. A study of success factors in advanced manufacturing technology deployment. Proceedings of the Second International Conference on Operation and Quantitative Management (ICOQM), India, 15-21.

Sari, K., 2007. Exploring the benefits of vendor managed inventory. International Journal of Physical Distribution and Logistics Management, 37 (7), 529-545.

Seyal, A., Rahman, M., and Mohammad, H., 2007. A quantitative analysis of factors contributing electronic data interchange adoption among Bruneian SMEs. Business Process Management Journal, 13 (5), 728-746.

Silveira, G., 2001. Innovation diffusion: research agenda for developing economies. Technovation 21, 767-773

Soares-Aguiar, A. and Palma-dos-Reis, A., 2008. Why do firms adopt e-procurement systems?: Using logistic regression to empirically test a conceptual model. IEEE Trans on Engineering Management, 55 (1), 120-133.

Song, D. and Dinwoodie, J., 2008. Quantifying the effectiveness of VMI and integrated inventory management in a supply chain with uncertain lead-times and uncertain demands. Production Planning and Control, 19 (6), 590-600.

Subramaniam, C. and Shaw, M.J., 2002. A study of the value and impact of B2B e-commerce: The case of web-based procurement. International Journal of Electronic Commerce, 6 (4), 19-40.

Tata, J., Prasad, S. and Thorn, R., 1999. The influence of organizational structure on the effectiveness of TQM programs. Journal of Managerial Issues, 11(4), 440-453.

Thailand Development Research Institute (TDRI), 1999. The development of Thailand's technological 
capability in industry report. Bangkok (in Thai).

Vigtil, A., 2007. Information exchange in vendor managed inventory. International Journal of Physical Distribution and Logistics Management, 37 (3), 131-147.

Wyld, D.C., 2002. The electric company: how the supply chain is being reinvented through the rapid application of e-procurement processes in the business-to-business arena. Management Research News, 25 (12), 22-53.

www.thaiauto.or.th.

Zhang, C., and Dhaliwal, J., 2009. An investigation of resource-based and institutional theoretic factors in technology adoption for operations and supply chain management. International Journal of Production Economics, 120 (1), 252-269.

Zhu, K., Kraemer, K., and Xu, S., 2003. Electronic business adoption by European firms: A cross-country assessment of the facilitators and inhibitors. European Journal of Information Systems, 12 (4), 251-268. 


\section{APPENDIX}

\section{A. Competitive/Business Focus - adapted from Childerhouse et al. (2003a)}

To what extent are the following practices/activities focused in your company in order to implement web-base order processing systems? (1) Strongly disagree to (6) strongly agree

A-1 Being the fast follower within the industry

A-2 Dealing with the technological change

A-3 Increasing the sustainable competitive advantage

A-4 Reducing the inventory level within the supply chain

A-5 Increasing the communication capability within the company

A-6 Increasing the data processing capability within company

A-7 Increasing the information transaction capability between company and customers

\section{B. Enabling Factors - adapted from Lyons et al. (2004), and Soares-Aguiar and Palma-dos-Reis (2008)}

To what extent are the following practices/activities implemented in your company for web-based order processing technology project? (1) not at all to (6) a great extent

B-1 We consider a level of knowledge and expertise of users before and after adopting webbased order processing technology

B-2 Continuous training and education for all interested parties has been provided before and after adopting web-based order processing technology

B-3 Ability of users to use electronic media in communicating with customers (assemblers) was taken into our account

B-4 We provided appropriate technological infrastructure computer including computer hardware/software, networks among users

B-5 Complexity of web-based order processing's feature/application was considered in the design stage of technology adoption. 
B-6 Top management commitment and financial support has been provided continuously

B-7 We has established both short-term (2-3 years) and long-term business plan (3-5 years) as required by customers (assemblers)

B-8 Frequency of data transactions among users was considered in the design stage of technology adoption

B-9 Operational capability among interested parties using the web-based technology was taken into account before adopting web-based order processing technology

B-10 Scope of system integration (inter-organization and intra-organization) has been considered in the design stage of technology adoption

B-11 Technological capability of system vendors or service providers was taken into account before adopting web-based order processing technology

B-12 We consider the efficiency and effectiveness of coordination \& communication among interested parties before and after adopting web-based order processing technology

\section{Expected Outcomes - adapted from Lauer (2000), and Leonard and Davis (2006)}

To what extent are following operational outcomes of your company compared with competitors? (1) Worst in industry to (6) best in industry

C-1 Increasing the degree of customer satisfaction

C-2 Increasing the ability to share information between company and customers

C-3 Reducing the loss of purchasing documents

C-4 Increasing accuracy in purchasing and production planning

C-5 Increasing the customer (assemblers) responsiveness

C-6 Reducing the cost of manufacturing of your company

C-7 Reducing inventory level of raw materials and work-in-process (WIP) 


\section{Barriers/Difficulties - adapted from Childerhouse et al. (2003b)}

To what extent are the following obstacles/difficulties important in implementing web-based order processing technology in your company? (1) Less important to (6) very important

D-1 Lack of capable network/system service provider

D-2 Inaccuracy of existing data in your company

D-3 Lack of coordination/communication between company and service provider

D-4 High frequency of software technological change

D-5 Incompatibility between existing data and software/operating used

D-6 Lack of customer (assemblers) support

D-7 High initial investment cost

D-8 Inadequate knowledge and skills of users

D-9 Lack of top management support 
Table 1 Respondents' characteristics.

\begin{tabular}{|c|c|c|}
\hline Characteristics of Respondents $(n=70)$ & Frequency & Percent \\
\hline \multicolumn{3}{|l|}{ Number of Employees } \\
\hline 200 or more & 45 & 64.3 \\
\hline Less than 200 & 25 & 35.7 \\
\hline \multicolumn{3}{|l|}{ Existing Labour Union } \\
\hline Yes & 23 & 32.85 \\
\hline No & 47 & 67.15 \\
\hline \multicolumn{3}{|l|}{ Ownership } \\
\hline Thai-owned & 13 & 18.6 \\
\hline Foreign-owned & 20 & 28.6 \\
\hline Joint-venture & 37 & 52.8 \\
\hline \multicolumn{3}{|l|}{ Manufactured Parts/Components } \\
\hline Accessories Parts & 6 & 8.6 \\
\hline Stamping Parts & 6 & 8.6 \\
\hline Suspensions Parts & 6 & 8.6 \\
\hline Frame and Body Parts & 11 & 15.6 \\
\hline Power Transmission Parts & 13 & 18.6 \\
\hline Electrical Parts & 14 & 20.0 \\
\hline Engine & 14 & 20.0 \\
\hline \multicolumn{3}{|c|}{ Years of Experience in Production Planning and Control Function } \\
\hline More than 10 & 14 & 20.0 \\
\hline $6-10$ & 22 & 31.4 \\
\hline $2-5$ & 25 & 35.7 \\
\hline Less than 2 & 9 & 12.9 \\
\hline \multicolumn{3}{|l|}{ Management System Certification } \\
\hline ISO9001/14001 and ISO/TS-16949 & 42 & 60.0 \\
\hline ISO9001 & 7 & 11.4 \\
\hline ISO14001 & 14 & 20.0 \\
\hline ISO/TS-16949 & 7 & 8.6 \\
\hline
\end{tabular}


Table 2 Motivation (rotated component matrix).

\begin{tabular}{lcccc}
\hline Constructs/Measured Variables & $\begin{array}{c}\text { Average } \\
\text { (Standard } \\
\text { Deviation) }\end{array}$ & $\begin{array}{c}\text { Factor } \\
\text { Loadings }\end{array}$ & $\begin{array}{c}\text { \% of } \\
\text { Variance }\end{array}$ & $\begin{array}{c}\text { Internal } \\
\text { Consistency }\end{array}$ \\
\hline $\begin{array}{l}\text { Improvement at Operational Level } \\
\text { Reducing the inventory level within the supply chain }\end{array}$ & $4.16(0.36)$ & 0.851 & & \\
$\begin{array}{l}\text { Increasing the communication capability within the } \\
\text { company }\end{array}$ & $4.37(0.28)$ & 0.818 & $36.335 \%$ & $\alpha=0.788$ \\
Increasing the ability in operational data processing & $4.66(0.45)$ & 0.773 & & \\
$\begin{array}{l}\text { Increasing information transaction capability } \\
\text { between company and customers }\end{array}$ & $5.19(0.17)$ & 0.599 & & \\
Long-term Strategy Focus & & & & \\
\hline To be the fast follower within the industry & $4.66(0.12)$ & 0.921 & $63.94 \%$ & 0.716 \\
Rapidly of Web-based technological change & $4.41(0.25)$ & 0.789 & & 0.706 \\
Increasing the competitive advantage & $4.46(0.32)$ & 0.606 & & 160.831 \\
Kaiser-Meyer-Olkin Measure of Sampling Adequacy & & & & 21 \\
Bartlett's Test of Sphericity: Approx. Chi-Square & & & & 0.000 \\
\hline $\begin{array}{l}\text { Df } \\
\text { Sig. }\end{array}$ & & & & \\
\hline
\end{tabular}


Table 3 Enabling factors (rotated component matrix)

\begin{tabular}{|c|c|c|c|c|}
\hline Constructs/Measured Variables & $\begin{array}{l}\text { Average } \\
\text { (Standard } \\
\text { Deviation) }\end{array}$ & $\begin{array}{l}\text { Factor } \\
\text { Loadings }\end{array}$ & $\begin{array}{l}\text { \% of } \\
\text { Varianc } \\
\text { e }\end{array}$ & $\begin{array}{l}\text { Internal } \\
\text { Consistency }\end{array}$ \\
\hline \multicolumn{5}{|l|}{ Technology Readiness } \\
\hline Knowledge/expertise of web-based technology's user & $4.97(0.24)$ & 0.815 & \multirow{4}{*}{$26.09 \%$} & \multirow{4}{*}{$\alpha=0.871$} \\
\hline $\begin{array}{l}\text { Continuous training and education for all interested } \\
\text { parties }\end{array}$ & $5.01(0.22)$ & 0.795 & & \\
\hline $\begin{array}{l}\text { Ability to use electronic media in communicating with } \\
\text { customers }\end{array}$ & $4.93(0.36)$ & 0.764 & & \\
\hline $\begin{array}{l}\text { Technological infrastructure (i.e. hardware/software, } \\
\text { networks) of users } \\
\text { Leadership }\end{array}$ & $4.94(0.48)$ & 0.626 & & \\
\hline Top management commitment and financial support & $5.14(0.35)$ & 0.879 & \multirow{4}{*}{$51.56 \%$} & \multirow{4}{*}{$\alpha=0.836$} \\
\hline Establishing the long-term plan & $4.69(0.42)$ & 0.794 & & \\
\hline Frequency of data transactions among users & $4.76(0.21)$ & 0.723 & & \\
\hline $\begin{array}{l}\text { Operational ability among interested parties using } \\
\text { the web-based technology } \\
\text { System Integration }\end{array}$ & $4.83(0.43)$ & 0.708 & & \\
\hline $\begin{array}{l}\text { Scope of system implementation (inter-organization } \\
\text { and intra-organization) }\end{array}$ & $4.61(0.21)$ & 0.815 & \multirow[t]{3}{*}{$72.68 \%$} & \multirow[t]{3}{*}{$\alpha=0.826$} \\
\hline Technological capability of systems vendors & $4.86(0.47)$ & 0.769 & & \\
\hline $\begin{array}{l}\text { Coordination \& communication among interested } \\
\text { parties }\end{array}$ & $4.84(0.33)$ & 0.734 & & \\
\hline Kaiser-Meyer-Olkin Measure of Sampling Adequacy & & & & 0.830 \\
\hline Bartlett's Test of Sphericity: Approx. Chi-Square & & & & 491.920 \\
\hline Df & & & & 66 \\
\hline Sig. & & & & 0.000 \\
\hline
\end{tabular}


Table 4 Implementation outcomes (rotated component matrix).

\begin{tabular}{|c|c|c|c|c|}
\hline Constructs/Measured Variables & $\begin{array}{l}\text { Average } \\
\text { (Standard } \\
\text { Deviation) }\end{array}$ & $\begin{array}{l}\text { Factor } \\
\text { Loadings }\end{array}$ & $\begin{array}{c}\% \text { of } \\
\text { Variance }\end{array}$ & $\begin{array}{c}\text { Internal } \\
\text { Consistency }\end{array}$ \\
\hline \multicolumn{5}{|l|}{ Customer responsiveness } \\
\hline Increasing the degree of customer satisfaction & $5.11(0.43)$ & 0.893 & \multirow{7}{*}{$84.12 \%$} & \multirow{7}{*}{$\alpha=0.865$} \\
\hline $\begin{array}{l}\text { Increasing the ability to share data between company } \\
\text { and customers }\end{array}$ & $4.94(0.19)$ & 0.854 & & \\
\hline Reducing the loss of purchased order documents & $5.04(0.22)$ & 0.771 & & \\
\hline $\begin{array}{l}\text { Increasing accuracy in purchasing and production } \\
\text { planning }\end{array}$ & $5.04(0.34)$ & 0.766 & & \\
\hline Increasing the customer (assemblers) responsiveness & $4.73(0.41)$ & 0.758 & & \\
\hline Reducing the cost of manufacturing of your company & $4.86(0.30)$ & 0.754 & & \\
\hline Reducing inventory level of raw materials and WIP & $4.27(0.57)$ & 0.632 & & \\
\hline Kaiser-Meyer-Olkin Measure of Sampling Adequacy & & & & 0.833 \\
\hline Bartlett's Test of Sphericity: Approx. Chi-Square & & & & 390.678 \\
\hline Df & & & & 45 \\
\hline Sig. & & & & 0.000 \\
\hline
\end{tabular}


Table 5 Barriers/difficulties.

\begin{tabular}{|c|c|c|c|c|}
\hline Constructs/Measured Variables & $\begin{array}{l}\text { Average } \\
\text { (Standard } \\
\text { Deviation) }\end{array}$ & $\begin{array}{l}\text { Factor } \\
\text { Loadings }\end{array}$ & $\begin{array}{c}\% \text { of } \\
\text { Variance }\end{array}$ & $\begin{array}{c}\text { Internal } \\
\text { Consistency }\end{array}$ \\
\hline \multicolumn{5}{|l|}{ Deployment Capability } \\
\hline Lack of capable network/system service provider & $3.33(0.99)$ & 0.844 & \multirow{6}{*}{$43.39 \%$} & \multirow{6}{*}{$\alpha=0.908$} \\
\hline Inaccuracy of existing data in your company & 3.35 (1.08) & 0.794 & & \\
\hline $\begin{array}{l}\text { Lack of coordination and communication between } \\
\text { company and service provider }\end{array}$ & $3.32(1.02)$ & 0.787 & & \\
\hline High frequency of software technological change & $4.41(0.86)$ & 0.779 & & \\
\hline $\begin{array}{l}\text { Incompatibility between existing data and applicable } \\
\text { software/operating system }\end{array}$ & $3.68(1.04)$ & 0.725 & & \\
\hline $\begin{array}{l}\text { Lack of customer (assemblers) support } \\
\text { Leadership }\end{array}$ & $3.32(1.01)$ & 0.719 & & \\
\hline High initial investment cost & $4.67(1.06)$ & 0.855 & \multirow{3}{*}{$51.56 \%$} & \multirow{3}{*}{$\alpha=0.836$} \\
\hline Inadequate knowledge and skills of users & $4.26(1.23)$ & 0.806 & & \\
\hline Lack of top management support & $3.33(0.97)$ & 0.653 & & \\
\hline Kaiser-Meyer-Olkin Measure of Sampling Adequacy & & & & 0.804 \\
\hline Bartlett's Test of Sphericity: Approx. Chi-Square & & & & 382.729 \\
\hline Df & & & & 36 \\
\hline Sig. & & & & 0.000 \\
\hline
\end{tabular}


Table 6 Multiple linear regression models based on size of company.

\begin{tabular}{|c|c|c|c|c|c|c|}
\hline ustomer responsiveness = & -.057 & $.157 X_{1}$ & - & $.032 x_{2}$ & + & $.650 X_{3}$ \\
\hline (t-value) & -.260 & -.651 & & -.177 & & 2.307 \\
\hline (Sig.) & .798 & .524 & & .861 & & .034 \\
\hline
\end{tabular}

Large size company (Cluster $2=45$ companies) : $\Delta R^{2}=0.247, F=4.925$, Sig. $=0.006$

$\begin{array}{rccccc}\text { Customer responsiveness }= & .152 & +\quad .272 \mathrm{X}_{1} & +\quad . \mathbf{4 8 8} \mathbf{X}_{2} & + & .056 \mathrm{X}_{3} \\ \text { (t-value) } & 1.082 & \mathbf{2 . 0 0 9} & & \mathbf{3 . 3 0 0} & 0.411 \\ \text { (Sig.) } & .287 & \mathbf{0 4 4} & & \mathbf{. 0 0 2} & 0.683\end{array}$

Where $X_{1}=$ Technology Readiness

$\mathrm{X}_{2}=$ Leadership

$X_{3}=$ Systems Integration 
Table 7 Multiple linear regression models based on existence of a labour union.

\begin{tabular}{|c|c|c|c|c|c|c|c|}
\hline Company with labour unic & (Cluster & $=21$ & mpanie & - & $59, F=4.3$ & Sic & $=0.036$ \\
\hline $\begin{array}{r}\text { Customer responsiveness }= \\
\text { (t-value) } \\
\text { (Sig.) }\end{array}$ & $\begin{array}{l}-.688 \\
-2.327 \\
.045\end{array}$ & - & $\begin{array}{l}.171 X_{1} \\
-.959 \\
.362\end{array}$ & + & $\begin{array}{c}1.081 X_{2} \\
2.933 \\
.017\end{array}$ & + & $\begin{array}{l}.581 X_{3} \\
2.209 \\
.055\end{array}$ \\
\hline Company without labour $u$ & on (Clust & $2=$ & compani & $\Delta R^{2}$ & $.240, F=5$ & 27,5 & $g .=0.003$ \\
\hline $\begin{array}{r}\text { Customer responsiveness }= \\
\text { (t-value) } \\
\text { (Sig.) }\end{array}$ & $\begin{array}{l}-.114 \\
-.797 \\
.430\end{array}$ & + & $\begin{array}{c}.356 X_{1} \\
2.146 \\
.038\end{array}$ & - & $\begin{array}{l}.065 X_{2} \\
-.428 \\
.671\end{array}$ & + & $\begin{array}{c}.526 X_{3} \\
3.712 \\
0.01\end{array}$ \\
\hline Where $\begin{aligned} \mathrm{X}_{1} & =\text { Technology } \\
\mathrm{X}_{2} & =\text { Leadership } \\
\mathrm{X}_{3} & =\text { Systems Int }\end{aligned}$ & $\begin{array}{l}\text { eadiness } \\
\text { ration }\end{array}$ & & & & & & \\
\hline
\end{tabular}

